\title{
Manfaat Akuntansi Pertanggungjawaban Dalam Pengendalian Biaya Administrasi dan Umum
}

\author{
Jusmani ${ }^{1}$, Mursalin ${ }^{2}$ \\ ${ }^{1}$ Akuntansi, FE Universitas PGRI Palembang, jusmani@univpgri-palembang.ac.id \\ ${ }^{2}$ Akuntansi, Fakultas Ekonomi, Univ. PGRI Palembang, mursalin@univpgri-palembang.ac.id
}

\begin{abstract}
ABSTRAK
Informasi akuntansi pertanggungjawaban merupakan informasi yang penting dalam proses perencanaan dan pengendalian aktivitas organisasi, karena informasi tersebut menekankan hubungan antara informasi dengan manajer yang bertanggung jawab terhadap perencanaan anggaran dan realisasinya. Pengendalian dapat dilakukan dengan cara memberikam peran bagi setiap manajer untuk merencanakan pendapatan /biaya yang menjadi tanggungjawabnya, dan kemudian menyajikan informasi realisasi pendapatan /biaya tersebut. Dalam proses penyusunan anggaran, setiap manajer diberi peran untuk mencapai sasaran perusahaan dan untuk memungkinkan konsumsi berbagai sumber daya yang harus diukur dalam satuan uang. Informasi akuntansi yang dihubungkan dengan manajer yang memiliki peran digunakan untuk mengukur kinerja setiap manajer. Salah satunya adalah pertanggungjawaban biaya administrasi dan umum.
\end{abstract}

Kata kunci: Akuntansi Pertanggungjawaban, Biaya Admistrasi dan Umum, Anggaran.

\begin{abstract}
Accountability accounting information is important information in the planning process and control of organizational activities, because it emphasizes the relationship between information and managers who are responsible for budget planning and its realization. Control can be done by giving a role for each manager to plan the income / expense for which he is responsible, and then to present information on the realization of the income / expense. In the budget preparation process, each manager is given a role to achieve the company's goals and to allow the consumption of various resources which must be measured in money units. Accounting information that is linked to managers who have a role is used to measure the performance of each manager. One of them is the accountability of administrative and general costs.
\end{abstract}

Keywords: Responsibility Accounting, Administration and General Costs, Budget.

\section{A. PENDAHULUAN}

Pengendalian manajemen adalah proses yang dilaksanakan oleh manajemen untuk menjamin bahwa sumber-sumber yang diperoleh dan digunakan dengan efektif dan efisien dalam rangka pelaksanaan strategi dasar yang telah ditentukan untuk mencapai tujuan organisasi. Kegiatan perencanaan ini akan menghasilkan seperangkat tujuan organisasi dan beberapa strategi sebagai kebijaksanaan yang menuntut adanya tindakan untuk mencapai tujuan tersebut.
Pusat-pusat pertanggungjawaban yang ada dalam organisasi perusahaan adalah pusat biaya, pusat pendapatan, pusat laba dan pusat investasi. Sehubungan dengan hal tersebut, maka pihak manajemen pusat membutuhkan suatu informasi yang dapat menunjukkan skala aktivitas kegiatan setiap pusat pertanggungjawaban, yang akan digunakan sebagai salah satu indikator dalam menilai pertanggungjawaban pelaksanaan wewenang yang telah diberikan oleh manajer pusat kepada manajer pusat pertangungjawaban. 
Jenis informasi yang dimaksud adalah "Informasi akuntansi

pertanggungjawaban".

Semua aktivitas ekonomi yang dilakukan oleh suatu organisasi atau perusahaan yang akan diproses dalam suatu sistem yang disebut sistem informasi akuntansi. Sistem ini dirancang sedemikian rupa oleh perusahaan sehingga dapat memenuhi fungsinya yaitu menghasilkan Informasi akuntansi yang tepat waktu, yang relevan dan dapat dipercaya.

Dalam suatu sistem informasi akuntansi terkandung unsur-unsur pengendalian, maka baik buruknya sisten informasi akuntansi sangat mempengaruhi fungsi manajemen dalam melakukan pengendalian internal, karena informasi yang dihasilkan akan dijadikan salah satu dasar dalam pengambilan keputusan yang berkaitan dengan aktivitas perusahaan.

Konsep informasi akuntansi pertanggungjawaban telah mengalami perkembangan, sejalan dengan metode pengendalian biaya yang digunakan dalam perusahaan. Salah satu sistem yang dikembangkan dalam metode pengendalian biaya adalah sistem akuntansi pertanggungjawaban, yang terdiri dari sistem akuntansi pertanggungjawaban tradisional dan sistem akuntansi pertanggungjawaban kontemporer.

Konsep

akuntansi

pertanggungjawaban adalah salah satu sistem dan strategi yang banyak digunakan oleh organisasi komersial untuk meningkatan efesiensi dan produktivitas. Maksud utama dari organisasi komersial adalah memperoleh laba. Ukuran keberhasilan untuk organisasi yang berorientasi pada laba adalah seberapa besar laba yang telah diperoleh atau setidak-tidaknya laba merupakan bagian untuk mengukur keberhasilan organisasi.

B. KAJIAN TEORI

1) Pengertian

Pertanggungjawaban

Menurut Garrison, Ray H (1997 :

457) mendefenisikan Akuntansi pertanggungjawaban adalah sebagai berikut : Akuntansi Pertanggungjawaban adalah sistem akuntansi yang biayanya dibebankan kepada berbagai tingkat pimpinan menurut tempat kendali biaya itu dianggap berada, dengan para manajernya bertanggungjawab atas selisih yang terjadi antara hasil yang dianggarkan dan hasil sesungguhnya.

Menurut Mulyadi (2001 : 70) mendefinisikan Akuntansi pertanggungjawaban adalah sebagai berikut : Pertanggungjawaban adalah suatu sistem akuntansi yang disusun sedemikian rupa sehingga pengumpulan dan pelaporan biaya dan pendapatan dilakukan sesuai dengan pusat pertanggungjawaban dalam organisasi dengan tujuan agar dapat ditunjuk orang atau kelompok orang yang bertanggungjawab atas penyimpanan biaya dan pendapatan yang dianggarkan.

Terdapat tiga anggapan mengenai akuntansi pertanggungjawaban adalah :

1. Anggapan pertama adalah bahwa biaya dapat disusun menurut tingkat pertanggungjawaban pimpinan.

2. Anggapan kedua adalah bahwa biaya yang dibebankan kepada tingkat tertentu dapat dikendalikan pada tingkat itu oleh manajernya.

3. Anggapan ketiga adalah menunjukkan langkah-langkah yang terlibat dalam penyusunan anggaran. 
Dalam akuntansi biaya (perencanaan dan pengendalian), Menurut Milton F. Usry \& Adolph (1990 : 271), Laporan pertanggungjawaban pelaksanaan kerja mempunyai dua tujuan :

$>$ Memberikan informasi kepada manajer dan pengawasnya mengenai pelaksanaan kerja mereka dalam bidang- bidang yang menjadi tanggungjawabnya.

$>$ Mendorong para manajer dan pengawas untuk mengambil tindakan langsung yang diperlukan guna memperbaiki pelaksanaan kerja.

\section{2) Pengertian Sistem \\ Pengendalian Manajemen}

Menurut Munawir (2002), Sistem pengendalian manajemen adalah suatu proses atau kegiatan pada masing - masing pusat pertanggungjawaban yaitu di mana manajemen menjamin bahwa organisasi melaksanakan strateginya dengan efektif dan efisien. Proses pengendalian manajemen terdiri dari empat tahap yaitu :

$\checkmark$ Penyusunan program

$\checkmark$ Penyusunan anggaran

$\checkmark$ Pelaksanaan dan pengukuran,

$\checkmark$ Pelaporan dan analisis.

Teknik pengendalian akan efektif jika disertai dengan pengetahuan manajemen yang memadai mengenai aspek-aspek perilaku dalam sistem pengendalian.

Menurut Armanto ( 2006 : 15) Berdasarkan pertanggung jawaban

Konsep biaya ini digunakan dalam system pengendalian manajemen (SPM), yang terdiri atas :

$\checkmark$ Biaya terkendali (Controllable cost) adalah biaya yang dikeluarkan oleh suatu tempat biaya dan atas pengeluaran biaya tersebut seseorang harus bertanggungjawab. $\checkmark$ Biaya tak terkendali (UnControllable cost) adalah biaya yang tidak bisa dibebankan tanggung jawab pengeluarannya pada seorang manajer/pimpinan pusat biaya.

\section{3) Penggolongan pusat-pusat pertanggungjawaban}

Salah satu unsur sistem pengendalian manajemen adalah struktur pengendalian manajemen yang menggolongkan suatu organisasi kedalam

pusat-pusat pertanggungjawaban.

Dalam organisasi perusahaan, penentuan daerah pertanggungjawaban dan manajer yang bertanggungjawab dilaksanakan dengan menetapkan pusat-pusat pertanggungjawaban dan tolak ukur kinerjanya.

Menurut Abdul Halim \& Bambang Supomo (1995 : 120) Pusat pertanggungjawaban adalah bagian atau unit organisasi yang dipimpin oleh seorang manajer yang bertanggungjawab terhadap unit yang dipimpinnya. Pusat-pusat pertanggungjawaban tersebut dapat dikelompokkan menjadi :

a. Pusat biaya (expense center)

b. Pusat pendapatan (revenue center )

c. Pusat laba ( profit center)

d. Pusat investasi (invesment center)

\section{4) Pengertian Informasi Akuntansi Pertanggungjawaban}

Menurut Mulyadi (2001 : 15), "Informasi Akuntansi Pertanggungjawaban merupakan informasi yang penting dalam proses pengendalian manajemen karena informasi tersebut menekankan hubungan antara informasi keuangan manajer dengan manajer yang bertanggung jawab terhadap perencanaan dan pelaksanaannya". 
Konsep Informasi Akuntansi Pertanggungjawaban telah mengalami perkembangan, sejalan dengan metode pengendalian biaya yang digunakan dalam perusahaan. Dalam sistem akuntansi pertanggungjawaban merupakan informasi aktiva, pendapatan, dan biaya, yang dihubungkan dengan manajer yang bertanggungjawab atas pusat pertanggung jawaban tertentu. Akuntansi pertanggungjawaban menelusuri biaya, pendapatan, laba dan investasi untuk unit-unit organisasi secara individual. Setiap unit organisasi tersebut merupakan pusat pertanggungjawaban.

\section{5) Manfaat Informasi Akuntansi Pertanggungjawaban}

Informasi ini dapat berupa informasi historis yang berupa aktiva, pendapatan, dan/atau biaya masa lalu, dan dapat pula berupa informasi masa yang akan datang. Informasi Akuntansi Pertanggungjawaban yang berupa informasi masa yang akan datang bermanfaat untuk penyusunan anggaran. Sedangkan informasi akuntansi pertanggungjawaban yang berupa informasi masa lalu bermanfaat bagi :

1. Penilaian kinerja manajer pusat pertanggungjawaban

2. Pemotivasi manajer.

\section{6) Pengertian Biaya Administrasi}

Administrasi merupakan pranata sosial yang didalamnya terdapat berbagai disiplin ilmu yang saling berkaitan. Administrasi adalah organisasi dan manajemen. Dimana organisasi dapat berarti sebuah lembaga atau kumpulan kelompok fungsional.

Menurut Garrison, Ray H (1997 : 15) Biaya Adminisrasi adalah semua biaya pimpinan, organisasi dan biaya produksi atau pun pemasaran yang berkaitan dengan pengelolaan umum sebuah organisasi.

Pengendalian Biaya Administrasi dan umum agak sulit dibandingkan dengan pengendalian Biaya Overhead Pabrik, karena kurang dapat diramalkan dan tidak dapat dibakukan. Fungsi Administrasi dan Umum berhubungan dengan penetapan kebijaksanaan, perencanaan, pengarahan eksekutif dan pengendalian secara menyeluruh.

\section{PEMBAHASAN}

1) Manfaat dari penyusunan dan pelaporan Akuntansi Pertanggungjawaban

Akuntansi Pertanggungjawaban adalah Akuntansi yang biasanya dibebankan berbagai tingkat pimpinan,menurut tempat kendali biaya itu dianggap berada, dengan para manajer yang bertanggungjawab atas selisih yang terjadi antara hasil yang dianggarkan dan hasil yang sesungguhnya. Dengan demikian Akuntansi Pertanggungjawaban merupakan suatu sistem akuntansi yang disusun sedemikian rupa sehingga pengumpulan dan pelaporan biaya dan pendapatan dilakukan sesuai dengan pusat pertanggungjawaban dalam organisasi dengan tujuan agar dapat ditunjuk orang atau kelompok orang yang bertanggungjawab atas penyimpanan biaya dan pendapatan yang dianggarkan.

Gagasan dasar dibalik akuntansi pertanggungjawaban adalah bahwa kinerja setiap manajer harus dinilai menurut seberapa baik ia mengelola hal-hal yang langsung berada dalam kekuasaan atau kendalinya.

Berdasarkan teori diatas, maka dalam pelaksanaan Akuntansi Pertanggungjawaban pada Perusahaan umumnya telah dilaksanakan dengan baik, karena 
Sistem

Akuntansi

Pertanggungjawaban yang ada telah dirancang untuk mengumpulkan dan melaporkan semua biaya yang terjadi berdasarkan tiap-tiap pusat pertanggungjawaban yang ada. Hal ini dapat dilihat dari proses penyusunan laporan pertanggungjawaban yang telah dilaksanakan, dimana setiap pusat pertanggungjawaban yang ada di Perusahaan ini menyusun dan melaporkan pertanggungjawaban atas pelaksanaan pekerjaan dan aktivitas yang telah dilakukan.

Laporan pertanggungjawaban perbagian akan menjadi dasar dalam menyusun laporan pertanggungjawaban untuk tingkat yang lebih tinggi.

Laporan pertanggungjawaban yang dibuat, yaitu :

1. Rincian perbandingan anggaran biaya versus realisasi pertahun

2. Rekapitulasi perbandingan anggaran biaya versus realisasi tahunan.

Berdasarkan sistem akuntansi pertanggungjawaban yang ada di Perusahaan, dapat dilihat adanya suatu tindak lanjut dari manajemen untuk mengukur bagian/departemen yang dibebankan melalui anggaran yang telah ditetapkan dalam pelaksanaan operasinya. Sehingga dapat diketahui apabila terjadinya penyimpangan dalam pelaksanaan anggaran, oleh sebab itu setiap pusat pertanggungjawaban akan diminta pertanggungjawaban oleh sub bagian anggaran kepada setiap kepala bagian yang bertanggung jawab setiap bulannya. Dan untuk setiap tahunnya akan dibuat laporan tanggapan tahunan oleh masing-masing bagian atas penyimpangan yang terjadi.

Adanya Penyimpangan yang mungkin terjadi akan menjadi tolak ukur bagian yang dibebankan terhadap biaya tersebut, dengan menindak lanjutkan tersebut diharapkan dapat mengetahui penyebab terjadinya penyimpangan tersebut dan manajer juga harus dapat mengambil langkahlangkah positif untuk memperbaikinya.

\section{2) Peranan dari Sistem Akuntansi Pertanggungjawaban}

Secara teoritis sebelum akuntansi pertanggungjawaban disusun, terlebih dahulu yang harus mempelajari mengenai garis besar dari wewenang dan tanggung jawab yang ada dalam suatu perusahaan. Sistem akuntansi pertanggungjawaban sebaiknya dirancang sesuai dengan struktur organisasi yang ada agar mampu menyajikan laporan prestasi manajer tingkat pertanggungjawaban dalam mencapai suatu tujuan yang telah ditentukan oleh perusahaan.

Berdasarkan defenisi mengenai sistem akuntansi pertanggungjawaban yang ada di dalam suatu perusahaan, maka dalam pelaksanaan sistem akuntansi pertanggungjawaban yang ada pada Perusahaan ini dapat dikatakan sudah cukup baik. Hal ini dapat dilihat dari adanya pusat-pusat pertanggungjawaban yang terbentuk dari sistem pelimpahan wewenang dan tanggung jawab yang ada. Setiap pusat pertanggungjawaban dipimpin oleh seorang manajer atau kepala bagian yang bertanggungjawab atas bagian yang dipimpinnya serta mempunyai tanggung jawab kepada tingkat manajemen diatasnya.

Dengan adanya pembagian pusat pertanggungjawaban, maka setiap manajer yang ada di masing-masing bidang maupun dimasing-masing bagian bertanggung jawab atas pusat pertanggungjawaban masing-masing. Seperti pusat biaya, maka setiap manajer tersebut bertanggung jawab atas pengelolaan biaya yang menjadi tanggung jawabnya. 
Tanggung jawab yang dipegang oleh seorang manajer adalah dalam pelaksanaan rencana kerja yang telah dibuat oleh Perusahaan ini, mengharuskan agar kegiatan dijalankan berdasarkan anggaran biaya yang telah disusun dengan menerapkan disiplin anggaran. Dalam hal ini dapat kita ketahui bahwa manajer pusat pertanggungjawaban diberi peran atas pelaksanaan kerja dan pengelolaan biaya yang ada di bagiannya masing-masing. Wewenang yang dimiliki oleh seorang manajer adalah mampu mengendalikan sesuatu yang ada di bawahnya. Maka dalam pembagian tanggung jawab atas biaya yang setiap kali dikeluarkan, maka perusahaan membagi pembebanan biaya kepada pihak-pihak penerima beban antara lain : bagian yang mengeluarkan biaya itu sendiri, bagian lain dalam lingkup perusahaan, Unit lain dan kepada pihak ketiga diluar perusahaan.

Dari penjelasan diatas dapat dikatakan bahwa sistem akuntansi pertanggungjawaban telah berperan dan sangat bermanfaat di Perusahaan.

\section{3) Manfaat dari Menyusunan Anggaran}

Dalam penyusunan anggaran ini pada dasarnya merupakan proses penetapan peran dalam usaha untuk pencapaian sasaran perusahaan, maka penyusunan anggaran harus dilakukan dengan terencana dan terperinci. Hal ini sangat penting mengingat akan suatu anggaran yang dapat memungkinkan perusahaan untuk mengintegrasikan seluruh kegiatan perusahaan dan mampu mengkomunikasikan sasaran perusahaan ke seluruh tingkat manajemen yang ada. Sehingga perusahaan mampu menyeimbangkan antara pemasukan dan pengeluaran anggaran biayanya.
Anggaran biaya dibuat berdasarkan tingkat kegiatan yang direncanakan dan informasi keuangan yang ada serta tingkat kegiatan yang sebelumnya. Proses penyusunan anggaran memerlukan peran dari seoarang manajer baik dalam penyusunan maupun dalam persetujuannya. Sehingga dalam proses penetapan peran tidak bersifat kaku. Semua itu dapat diketahui apa yang menjadi kebutuhan dari tiap tingkat manajer yang tertinggi sampai ke tingkat manajer yang terendah.

Dalam penyusunan anggaran di perusahaan menggunakan pendekatan gabungan dari metode Top-Down dan Bottom-Up. Metode top-down terlihat jelas dari adanya partisipasi manajemen puncak dalam proses penyusunan anggaran. Hal ini sangat berguna dalam memotivasi para manajer dalam menyusun anggaran. Partisipasi dari manajemen puncak ini terletak pada penilaian dan pengesahan anggaran dan kebijaksanaan, bukan hanya sekedar membubuhkan tanda tangan saja. Sebab bila tidak ada partisipasi dari seorang manajer puncak maka dapat menimbulkan kecenderungan bagi para manajer untuk bermain-main dalam menyusun sistem anggaran. Metode bottom-up bisa dilihat dari partisipasi masing-masing bagian dalam membuat usulan anggaran. Usulan anggaran selalu diperiksa dan diteliti ditiap tingkat manajemen. Setelah disetujui oleh manajemen puncak (BPK), kemudian anggaran ini akan dikembalikan ke unit-unit yang mengusulkannya.

Dari penjelasan diatas dapat dikatakan bahwa akuntansi pertanggungjawaban sangat bermanfat bagi Perusahaan. Dengan terpenuhinya kondisi-kondisi. sebagai berikut : 
a. Manajer

pusat

pertanggungjawaban

telah

berperan serta dalam penentuan tujuan yang digunakan untuk mengukur prestasinya.

b. Adanya wewenang dan tanggung jawab melalui struktur organisasi yang ada

c. Manajer

pusat

pertanggungjawaban dipacu

untuk berusaha agar mampu mencapai tujuan yang telah ditentukan

d. Manajer

pusat

pertanggungjawaban

bertanggung jawab atas kegiatan yang dapat dikendalikan

e. Manajer pusat biaya yang dimasukkan dalam laporan pertanggungjawaban hanya bisa mengendalikan pusat biaya

f. Laporan prestasi dan umpan baliknya disajikan tepat waktu

g. Laporan prestasi menyajikan secara jelas selisih yang terjadi, dan langsung ditindak lanjuti.

\section{4) Manfaat dari menggunakan Informasi Akuntansi Pertanggung jawaban}

Manfaat dari sistem akuntansi pertanggungjawaban adalah adanya informasi akuntansi pertanggungjawaban yang dapat berupa informasi di masa lalu yang juga bermanfaat sebagai penilai kinerja manajer pusat pertanggungjawaban dan sebagai pemotivasi manajer. Sehingga informasi akuntansi pertanggungjawaban ini dapat digunakan sebagai dasar untuk menilai kinerja manajer pusat dan juga sebagai pemotivasi manajer pusat biaya yang bersangkutan.

Perusahaan ini dapat diketahui bahwa adanya pemberian peran kepada masing-masing pusat tanggung jawab melalui pengusulan anggaran untuk kegiatan yang akan dilaksanakan. Dari pemberian peran ini akan dinilai seberapa jauh pusat biaya dapat dilaksanakan, digunakan sesuai dengan perencanaan dan pengendalian aktivitas organisasi. Semua itu dapat dilihat dari laporan pertanggungjawaban biayanya. Dan kita juga dapat menilai apakah anggaran telah ditetapkan sesuai dengan ketentuan yang telah dibuat dan dilaksanakan secara efektif dan efesien.

Penilaian dari prestasi yang telah dilaksanakan oleh suatu bagian pusat pertanggungjawaban kemudian akan dilaporkan ke manajer masing-masing bagian tersebut. Hal ini mendorong setiap manajer untuk bekerja dengan sebaik mungkin karena bila hasil kerjanya tidak baik, maka manajer akan dimintai tanggung jawab melalui suatu rapat maupun suatu memo. Dengan pengukuran hasil kinerja dari setiap bagian ini, maka dapat dinilai apakah pusat biaya itu bekerja dengan efektif dan efesien. Bila dalam pusat biaya tersebut seluruh biaya yang telah dikeluarkan adalah benar-benar sesuai dengan seluruh kegiatan yang telah direncanakan berarti pusat biaya ini telah bekerja dengan efektif, Dimana manajer harus bertanggung jawab atas prestasi dan kinerja pusat biayanya. Prestasi kinerja seorang manajer dapat dinilai dengan ukuran informasi berupa hasil keputusan, kebijakkan, dan prosedur kerja yang dapat dilihat dari Realisasi yang dapat dicapai atas Anggaran yang dibebankan.

\section{5) Pengendalian}

Biaya

\section{Administrasi dan Umum}

Pengendalian Biaya Administrasi dan umum agak sulit dibandingkan dengan pengendalian Biaya Overhead Pabrik, karena kurang dapat diramalkan dan tidak dapat dibakukan. 
Fungsi Administrasi dan Umum berhubungan dengan penetapan kebijaksanaan, perencanaan, pengarahan eksekutif dan pengendalian secara menyeluruh.

Syarat penting bagi prosedur untuk pengendalian akuntansi yang dapat diterima antara lain :

1. Suatu klasifikasi yang baik dari perkiraan yang mengurai tentang biaya dalam perincian-perincian yang diperlukan,

2. Pelimpahan tanggung jawab pengendalian yang pasti kepada seorang individu.

Pengendalian adalah penentuan secara periodic efektivitas operasional suatu organisasi, bagian organisasi dan karyawannya berdasarkan sasaran, standar dan criteria yang telah ditetapkan sebelumnya.

Organisasi dapat diterjemahkan dari keseluruhan strategi kedalam suatu tujuan, baik jangka panjang maupun jangka pendek. Tujuan-tujuan tersebut menjadi dasar penyusunan anggaran. Anggaran merupakan suatu langkah untuk mencapai suatu tujuan perusahaan dalam jangka panjang dengan menterjemahkan dalam pencapaian rencana jangka pendek atau secara tahunan.

Anggaran sebagai alat pengendalian biaya yang merupakan penjabaran dari rencana/program kerja perusahaan, maka dalam penyusunan anggaran harus dimulai dari tiap unit/bagian dari perusahaan. Dengan demikian, hasil yang diperoleh dari penyusunan anggaran akan berbentuk Rencana kerja dan Anggaran perusahaan (RKAP) yang berjangka waktu satu tahun.

Adapun Salah satu syarat agar anggaran yang telah disusun dapat berhasil dengan baik yaitu dengan melibatnya semua unit dan manajemen dari berbagai jenjang organisasi dalam penyusunan anggaran. Hal ini dimaksudkan agar anggaran yang disusun benar-benar berdasarkan ketentuan dari masingmasing unit, sehingga mereka mempunyai rasa memiliki terhadap anggaran tersebut dan berusaha mencapai apa yang telah dianggarkan. Sasaran anggaran tidak akan tercapai tanpa pantauan secara terus menerus dari seoarang manajer pusat terhadap kemajuan karyawannya untuk mencapai tujuan yang telah ditetapkan.

Dalam menyusun anggaran diperlukan juga peran dari tiap-tiap kepala bagian atau manajer dalam penyusunan maupun persetujuannya, sehingga dalam proses penetapan peran tidak bersifat kaku dan dapat diketahui apa yang menjadi kebutuhan dari tiap manajer yang tertinggi sampai manajer tingkat terendah. Dengan memperhatikan uraian diatas ada begitu banyak jenjang dan tingkatan manajemen yang harus dilewati suatu usulan kerja hingga disetujui dan disahkan. Dari uraian diatas dapat dilihat bahwa Perusahaan menerapkan penganggaran partisipatif dalam proses penyusunan anggaran.

Yang dimaksud dari

Penganggaran partisipatif yaitu dapat memberikan rasa tanggung jawab kepada para manajer bawahan dan mendorong timbulnya kreativitas para manajer bawahan yang menciptakan anggaran. Maka besar kemungkinan tujuan pribadi manajer tersebut merupakan tujuan anggaran, yang menyebabkan semakin tingginya tingkat keselarasan tujuan. Meningkatnya rasa tanggung jawab serta tantangan merupakan intensif non moneter, yang pada akhirnya menjadikan pengendalian terhadap biaya akan semakin mudah. Penganggaran partisipatif ini memiliki beberapa masalah potensial, antara lain adalah penetapan standar yang 
terlalu tinggi ataupun terlalu rendah dan partisipasi semu.

Masalah potensial yang timbul dari diterapkannya penganggaran partisipatif bisa diatasi dengan menggunakan pendekatan gabungan dari metode top-down planning dan bottom-up dalam proses penyusunan anggaran. Gabungan dari kedua metode tersebut dapat menghasilkan anggaran yang tidak hanya berusaha dicapai oleh pihak yang mengusulkannya tetapi harus sesuai dengan tujuan dan kebijakkan perusahaan secara keseluruhan, karena anggaran yang diusulkan oleh menejer bawah dipelajari dan diperiksa kembali oleh BPK dan akan diberikan masukan yang dibutuhkan.

\section{6) Peranan dari Akuntansi Pertanggungjawaban dalam menunjang Pengendalian Biaya Administrasi dan Umum.}

Berikut ini adalah contoh perhitungan mengenai laporan anggaran realisasi biaya administrasi dan umum untuk tahun 2015-2019 adalah sebagai berikut:

\section{Tabel Laporan Realisasi Anggaran Untuk Tahun 2015}

\begin{tabular}{|l|r|r|}
\hline Beban Adm \& Umum & \multicolumn{1}{|c|}{ Anggaran } & \multicolumn{1}{c|}{ Realisasi } \\
\hline Biaya pemeliharaan sarana & 54.000 .000 & 53.000 .000 \\
\hline Biaya adm dan kantor & 85.000 .000 & 70.000 .000 \\
\hline Biaya pemeliharaan alat kantor & 15.000 .000 & 12.000 .000 \\
\hline Biaya pemeliharaan alat RT & 24.000 .000 & 23.000 .000 \\
\hline Biaya gaji dan upah & 2.560 .150 .850 & 1.660 .890 .575 \\
\hline Biaya makanan karyawan & 170.000 .000 & 158.000 .000 \\
\hline Biaya transportasi & 26.000 .000 & 24.000 .000 \\
\hline Biaya pemeliharaan gedung & 63.000 .000 & 62.800 .000 \\
\hline Biaya Engenering & 22.000 .000 & 21.500 .000 \\
\hline JUMLAH & $\mathbf{3 . 0 1 9 . 1 5 0 . 8 5 0}$ & $\mathbf{2 . 0 8 5 . 1 9 0 . 5 7 5}$ \\
\hline
\end{tabular}

Tabel Laporan Realisasi Anggaran Untuk Tahun 2016

\begin{tabular}{|l|r|r|}
\hline Beban Adm \& Umum & \multicolumn{1}{c|}{ Anggaran } & \multicolumn{1}{c|}{ Realisasi } \\
\hline Biaya pemeliharaan sarana & 94.000 .000 & 93.500 .000 \\
\hline Biaya adm dan kantor & 82.500 .000 & 76.000 .000 \\
\hline Biaya pemeliharaan alat kantor & 28.000 .000 & 27.500 .000 \\
\hline Biaya pemeliharaan alat RT & 96.000 .000 & 85.000 .000 \\
\hline Biaya gaij dan upah & 4.500 .800 .900 & 4.490 .750 .198 \\
\hline Biaya makanan karyawan & 198.000 .000 & 197.900 .000 \\
\hline Biaya transportasi & 64.000 .000 & 58.000 .000 \\
\hline Biaya pemeliharaan gedung & 67.000 .000 & 66.000 .000 \\
\hline Biaya Engenering & 65.000 .000 & 64.000 .000 \\
\hline JUMLAH & $\mathbf{5 . 1 9 5 . 3 5 0 . 9 0 0}$ & $\mathbf{5 . 1 5 9 . 6 0 0 . 1 9 8}$ \\
\hline
\end{tabular}


Tabel Laporan Realisasi Anggaran Untuk Tahun 2017

\begin{tabular}{|l|r|r|}
\hline Beban Adm \& Umum & \multicolumn{1}{c|}{ Anggaran } & \multicolumn{1}{c|}{ realisasi } \\
\hline Biaya pemeliharaan sarana & 96.000 .000 & 94.000 .000 \\
\hline Biaya adm dan kantor & 90.000 .000 & 82.000 .000 \\
\hline Biaya pemeliharaan alat kantor & 60.000 .000 & 50.000 .000 \\
\hline Biaya pemeliharaan alat RT & 100.000 .000 & 96.000 .000 \\
\hline Biaya gaji dan upah & 4.786 .170 .500 & 4.500 .900 .880 \\
\hline Biaya makanan karyawan & 225.000 .000 & 224.000 .000 \\
\hline Biaya transportasi & 170.000 .000 & 161.000 .000 \\
\hline Biaya pemeliharaan gedung & 190.000 .000 & 187.000 .000 \\
\hline Biaya Engenering & 160.000 .000 & 170.000 .000 \\
\hline JUMLAH & $\mathbf{5 . 8 7 7 . 1 7 0 . 5 0 0}$ & $\mathbf{5 . 5 6 4 . 9 0 0 . 8 8 0}$ \\
\hline
\end{tabular}

Tabel Laporan Realisasi Anggaran Untuk Tahun 2018

\begin{tabular}{|l|r|r|}
\hline Beban Adm \& Umum & \multicolumn{1}{c|}{ Anggaran } & \multicolumn{1}{c|}{ Realisasi } \\
\hline Biaya pemeliharaan sarana & 137.000 .000 & 135.000 .000 \\
\hline Biaya adm dan kantor & 163.000 .000 & 117.000 .000 \\
\hline Biaya pemeliharaan alat kantor & 64.000 .000 & 63.000 .000 \\
\hline Biaya pemeliharaan alat RT & 145.000 .000 & 141.000 .000 \\
\hline Biaya gaji dan upah & 11.500 .000 .000 & 9.650 .475 .600 \\
\hline Biaya makanan karyawan & 360.000 .000 & 260.000 .000 \\
\hline Biaya transportasi & 180.000 .000 & 156.000 .000 \\
\hline Biaya pemeliharaan gedung & 230.000 .000 & 210.000 .000 \\
\hline Biaya Engenering & 290.000 .000 & 275.000 .000 \\
\hline JUMLAH & $\mathbf{1 3 . 0 6 9 . 0 0 0 . 0 0 0}$ & $\mathbf{1 1 . 0 0 7 . 4 7 5 . 6 0 0}$ \\
\hline
\end{tabular}

Tabel Laporan Realisasi Anggaran Untuk Tahun 2019

\begin{tabular}{|l|r|r|}
\hline \multicolumn{1}{|c|}{ Beban Adm \& Umum } & \multicolumn{1}{c|}{ Anggaran } & \multicolumn{1}{c|}{ Realisasi } \\
\hline Biaya pemeliharaan sarana & 173.000 .000 & 155.000 .000 \\
\hline Biaya adm dan kantor & 480.000 .000 & 390.000 .000 \\
\hline Biaya pemeliharaan alat kantor & 82.000 .000 & 81.000 .000 \\
\hline Biaya pemeliharaan alat RT & 143.000 .000 & 141.000 .000 \\
\hline Biaya gaji dan upah & 16.000 .940 .680 & 14.580 .715 .600 \\
\hline Biaya makanan karyawan & 380.000 .000 & 330.000 .000 \\
\hline Biaya transportasi & 280.000 .000 & 260.000 .000 \\
\hline Biaya pemeliharaan gedung & 340.000 .000 & 315.000 .000 \\
\hline Biaya Engenering & 360.000 .000 & 340.000 .000 \\
\hline JUMLAH & $\mathbf{1 8 . 2 3 8 . 9 4 0 . 6 8 0}$ & $\mathbf{1 6 . 5 9 2 . 7 1 5 . 6 0 0}$ \\
\hline
\end{tabular}

Berdasarkan ilustrasi data tersebut dimana dalam biaya administrasi dan umumnya mengalami perkembangan cukup baik. Hal tersebut dibuktikan penulis dengan membuat suatu laporan perbandingan 
dari tahun dasar yaitu 2015 hingga tahun 2019 bahwa terlihat dalam laporan biaya administrasi dan umum dapat terkendali dengan cukup baik.
Hal tersebut dapat dilihat dari tabel yang akan dipaparkan dibawah ini terhitung dari Tahun 2015 sampai tahun 2019.

Analisis Trend Laporan Realisasi Anggaran pada Biaya Administrasi dan Umum

Tahun 2015 sampai 2019 adalah sebagai berikut :

\begin{tabular}{|c|c|c|c|c|c|}
\hline Tahun & Anggaran & Realisasi & $\begin{array}{c}\text { Analisis } \\
\text { Selisih }\end{array}$ & $\%$ & F/UF \\
\hline 2015 & 3.019 .150 .150 & 2.085 .190 .575 & 933.960 .275 & $30,96 \%$ & $\mathrm{~F}$ \\
\hline 2016 & 5.159 .350 .900 & 5.159 .600 .198 & 35.750 .702 & $0.69 \%$ & $\mathrm{~F}$ \\
\hline 2017 & 5.877 .170 .500 & 5.564 .950 .880 & 312.269 .620 & $5,31 \%$ & $\mathrm{~F}$ \\
\hline 2018 & 13.069 .000 .000 & 11.007 .475 .600 & 2.061 .524 .400 & $15,77 \%$ & $\mathrm{~F}$ \\
\hline 2019 & 18.238 .950 .680 & 16.592 .715 .600 & 1.646 .225 .080 & $9,02 \%$ & $\mathrm{~F}$ \\
\hline JUMLAH & $\mathbf{4 5 . 3 9 8 . 6 2 2 . 9 3 0}$ & $\mathbf{4 0 . 4 0 9 . 8 8 2 . 8 5 3}$ & $\mathbf{4 . 9 8 8 . 7 4 0 . 0 7 7}$ & $\mathbf{1 0 , 9 8 \%}$ & $\mathbf{F}$ \\
\hline
\end{tabular}

Keterangan :

F : Favorable (terkendali)

UF : Unfavorable ( tak terkendali)

Jadi, penulis menyimpulkan dari trend laporan realisasi anggaran biaya administrasi dan umum tahun 2015 sampai 2019 bahwa dalam laporan realisasi anggaran biaya administrasi dan umum ini telah dijalankan dengan cukup baik sesuai dengan anggaran yang telah ditentukan sebelumnya. Anggarannya adalah 45.398.622.930. sedangkan realisasinya adalah 40.409.822.853. Selisihnya adalah 4.988.740.977. Persentasenya adalah $10,99 \%$ dan dapat disimpulkan bahwa semua biaya yang telah tentukan dapat dikendalikan dengan cukup baik. Hal tersebut dapat dilihat dari tabel yang dipaparkan diatas. Apabila realisasi effisien dan relatif terhadap standar anggaran maka dapat dikatakan biaya administrasi dan umum telah terkendali (favorable).

\section{KESIMPULAN}

Berdasarkan pembahasan yang telah dilakukan sebelumnya, maka kesimpulan dan saran untuk penulisan skripsi ini adalah sebagai berikut:

1. Akuntansi pertanggungjawaban berperan dalam pengendalian biaya administrasi dan umum pada Perusahaan berdasarkan data yang didapat yang di analisis dan di deskripsikan mengenai anggaran dan realisasi biaya administrasi dan umum.

2. Sistem akuntansi pertanggungjawaban yang ada di Perusahaan telah dilaksanakan dengan cukup baik, dilihat dari cara pembuatan susunan laporan aktivitas akan biaya administrasi dan umum terhadap biaya yang dikeluarkan dapat dikendalikan dengan baik.

3. Di dalam Trend laporan realisasi anggaran biaya administrasi dan 
umum tahun 2015 sampai 2019 mengenai laporan realisasi anggaran biaya administrasi dan umum ini telah dijalankan dengan cukup baik sesuai dengan anggaran yang telah ditentukan sebelumnya.

\section{DAFTAR PUSTAKA}

Halim, Abdul \& Supomo, Bambang, 1995, Akuntansi manajemen, BPFE, Yogyakarta.

Mulyadi, 2001, Akuntansi Manajemen 2: Konsep, Manfaat dan
Rekayasa, STIE YKPN, Yogyakarta.

Munawir, 2002, Akuntansi keuangan dan Manajemen, BPFE, Yogyakarta.

Ray H, Garrison, 1997, Akuntansi Manajemen Konsep Untuk Perencanaan, Pengendalian dan Pengambilan keputusan, ITB, Bandung.

Usry, Milton \& Matz, Adolph, 1990, Akuntansi Biaya: Perencanaan dan Pengendalian, Erlangga, Jakarta.

Witjaksono, Armanto, 2006, Akuntansi Biaya, Graha IImu, Yogyakarta. 